\title{
The Crossing Border of Post-Feminist Subject: The Search for Indonesian Contextual Women
}

\author{
Aprinus Salam \\ Universitas Gadjah Mada \\ Yogyakarta, Indonesia \\ aprinus@ugm.ac.id
}

\author{
Ali Mustofa \\ Universitas Negeri Surabaya \\ Surabaya, Indonesia \\ alimustofa@unesa.ac.id
}

\begin{abstract}
This paper seeks to explain how postfeminist theory is being framed in accordance with its contextual conditions of each culture of society. Formerly, post-feminism has interacted with poststructuralism as its basic epistemological development. In its later development, post-feminism has come across with postcolonialism, postmodernism, and local culture. For Indonesian context, in fact, these conditions of intersection are important. The purpose of this paper is to find out possible post-feminists' "challenges and opportunities" to bring up contextual women to their own culture and nature.
\end{abstract}

Keywords-post-feminism, post-structuralism, postcolonialism, post-modernism, contextual women

\section{INTRODUCTION}

The development of feminist studies to postfeminism has brought the study into a more contextual realm. Initially, feminist studies or theories questioned the dominance (and hegemony) of the patriarchal order, and the rational efforts to dismantle the inequalities of women's civil rights in the economic, political, social and cultural fields. The feminist theory base departs from structural epistemology with the concept of binary opposition[[1];[2];[3]]. Successful feminist studies into the mainstream (hegemonic feminism) in these interdisciplinary studies still leave a variety of epistemological issues, which are then questioned and developed by postfeminist thinkers.

Post-feminist studies later bring the study to a more specific realm by bringing it up into different spaces, taking into account the interrelationships of religion, ethnicity, race, age, education, and cultural values of a particular locale. Post-feminism significantly collaborates with post-structuralism, postmodernism, and postcolonialism [1] or "boundary crossing" [3]. The study of postfeminism becomes important for the Indonesian context by questioning how the condition of Indonesian women to be postfeminist based on social and cultural conditions

This paper delivers a few questions. Firstly, how is the correlation of discourse of postfeminism with poststructuralism, postmodernism, and postcolonialism? Secondly, how is the postfeminist formation in the middle, and dealing with, the dynamics of the changes and the demands of identity made into possibility by its social context? Both questions are at the same time addressing the main issues by questioning the "opportunities and challenges" of postfeminist subject in Indonesia. Later on, the question which triggers the research will be on the "opportunities and challenges" which lead to the form of contextual women.

For that matter, it should also be explaining about the definition of discourse, ideology, subject, feminine, and identity. The concept and the use of the word "discourse" is quite diverse. The word is used by most scientific disciplines, and there are a number of discourses or concepts of discourse with different focus and paradigms. Following Foucault's ideas [5] states thata discourse can be interpreted as the field of all statements, sometimes as an individualization of a group of statements, and sometimes as a regulative practice seen from a number of statements [5]. These statements, however, are bound in a discursive structure that causes the discourse to be meaningful.

Discourse can be a force that has its own rules of organizing things, organizing a discursive practice. It is the wisdom that determines what is to be said and what is not supposed to be discussed, who is allowed to speak and who is not, how to speak the allowable and the forbidden [6] [7]. Likewise, [8] states that discourse can be interpreted as a specific way of speaking, writing, and thinking, and the practice of language is concerned with the social relations behind the practice. As a practice, discourse is significantly determined by history and time. That is, very likely in such discursive practice, a person has a particular purpose and interest, in its various implications.

The use of the word subject has existed since science was developed, with the concept of the subject of enlightenment, rational subjects, and so forth. In the beginning, the sense of the subject when man is placed as a thing based on his own ability, based on his rationality, his existence as something formed himself. However, many things of the concept are not able to answer the problem, for example, how to explain the changes that occur on the subject. That is why, the understanding of the subject undergoes many shifts. 
The subject is an understanding related to the discourses that constitute a person's "consciousness". As has been understood, there are a number of discourses that make up the subject. In the diversity of the discourse there is a dominant discourse in its relations with other discourse. In the dominant (and hegemonic) discourse of the discourse, the subject is positioned and positioned in his or her life order. That is why, there many terms related to the terms of modern subject, postcolonial subject, postmodern subject, feminist subject, or postfeminist subject, and so on. It shows that the subject is unstable [9].

Understanding the word identity can not be released with an understanding of the subject. If the subject is more as an individual's internal condition, identity is meant as an external situation [10]. The things of the assessment and classification of the symbolic differences of the subject are identities that "coordinate" directly with the existence of the subject[11]. Contestation and negotiation within the subject, which appears (externally) in the form of attitude, action, appearance, and other decisions, and usually grouping, is something called as identity. In the meantime, the feminine thing here is the overall quality of femininity based on femininity itself by considering it as a posfeminist subject.

Thus, the paper will explain the following principles. First, the explanation of various crossings between postfeminism with poststructuralism, postcolonialism, and postmodernism. Second, explaining the postfeminist subject in relation to the feminine formation. The explanation of feminine formation in relation to postfeminine identity politics in relation to the search for contextual women (in Indonesia).

\section{THE INTERSECTION WITH POST- STRUCTURALISM}

The intersection of postfeminism with poststructuralism exists especially at the level of espistemology. It is something more abstract than of the social empirical problems, politics, economy, and culture. The stereotype is when postfeminism is aware of the point of the intersection, and at the same time the point of separation, of the things that the structural theories have developed as shown by studies in the Marxist tradition. In the early Marxism, structural-based theory became the main focus in building assumptions about the reality of life.

From this point, it can be drawn a conclusion that an order is an imaginary relation between the dominant and the dominated. The dominant party will maintain its dominant position with various rules and other discourses that support and maintain its dominance. The success of a dominant position is measured if the dominated party feels not dominated so as to live a natural life.
This dominant takes control of the structure which does not only occur in economic, political, or social relations, but also overlaps in relation to gender relations. Building a patriarchal world is the dominant relationship which is dominated by gender relations and by placing women as subordinate [12]. From the structure of binary opposition, this is the beginning of departure for feminist theories that attempt to overhaul the structure of patriarchal domination. This feminist thinking became mainstream, resulting in many changes in society. However, in the future, the problem is not yet resolved when the "status of equality" is not as envisaged by postfeminist thinkers and hence women are still dichotomized or posed to men.

Postfeminism adopts post-structural theory by placing its subject position not within the framework of the patriarchal discursive structure, but building its own or[3]. There are several overlapping matters relating to epistemology in positioning the postfeminist subject between the foundations of post-structuralism and postmodernism. In some studies, thinkers such as Helen Cixous, Luce Irigaray, and Julia Kristeva are placed as positivist feminist thinkers. The postmodern feminist is how to get women out of the binary opposition of the economy (the dominance of the patirarchic order), by developing the subject itself when women are abandoned. In this position, women independently build their existential subject by using their own language, empowering their own skills and appearance, and exercising their own criteria.Even Cixous is a bit more extreme when saying that sexually women may become independent by doing lesbian and ecobiotic. It is also related with the consideration that female erotic geography is much larger and broader than male's [3]. Although this is placed as a postmodern feminists' idea, the explanation departs from the thought of post structuralist.

The post-structuralist's epistemology that questions humanism is also adopted by postfeminism. Humanism is a paradigmatic comprehension that "equates" the human aspect, that which is the human subject. The problem is human in terms of what and who, if then the human is precisely in the domination and hegemony of his patriarchal human. The notion is also related to "mankind" concepts, not "womankind". In this context, postfeminismis not again willing to follow "mankind" humanism, because they want to develop what is the so called of "womankind". The same thing happen with history and shestory issues.

Another important point that needs to be clarified is the identification of the "sex" of the dominant structure that causes the power of discourse and at the same time determines the subject positions. Based on the Marxist studies, differences in production of ownership led to the 
emergence of social classes. The owner of the means of production (economic ruler), will retain his position in various ways, either by means of mastery of the ideology itself or by repressive means. Practically, the circulation of the profits of economic production flows into the bourgeoisie (the economic ruler). This is where the system and structure of capitalism work.

In Marxist studies, the theories do not question the issue of gender. However, it can be seen that the owner of the means of production (the bourgeoisie) is dominated by patriarchy. That is why, seeing the dominant structure that occurs, the structure of capitalism is a masculine sexed. In the structure of masculine capitalism, it is evident that not only commodified labor, but women also become commodities.

Thus, it is logical that postfeminism rejects the dominant structure. The rejection is epistemological. That is why postfeminism builds a paradigm outside the dominant structure, and that paradigm is obviously post-structuralist, or in the crossing border with postmodernism, the cultural paradigm. The problem is not merely the transfer of paradigm, but post-feminism also deconstructs the paradigm that encapsulates feminism.

Another important thing that is adopted by postfeminist is Derrida's and Foucault'sideas. From Derrida, postfeminists are indebted primarily to deconstruction efforts on the centralization of meaning, especially oppositional concepts. There is no concentration of meaning, and if it is still preserved then it is a patriarchal construction. That is why, postfeminist also agrees that in addition to a stable center of meaning which must be rejected, meaning is an unfinished process. This is directly related to the rejection of the monopoly of interpretation or truth, which overlaps with the postmodern paradigm.

Foucault's important point to underline is that he warns of the power of a discursive regime that oppresses its structure, especially if it is associated with gender, class, and race. Postfeminism builds a paradigm based on that awareness. Postfeminists ${ }^{6}$ efforts is to get out of the power of discursive regime which is masculine/patriarchicand is to continuously build a new discourse in the internal structure within its own boundaries, for example language issues, feelings, choices and decisions of life [1].

\section{INTERSECTION WITH POSTCOLONIALISM}

The intersection of postfeminism with postcolonialism, rather than identifying postfeminist'boundary crossing with poststructuralism and/or postmodernism, provides a different stressing point. The meeting point of postfeminism and post-structuralism is more on the epitemological grounds, and then its intertwinning point with postmodernism is more on the establishment of the classification and identity of femininity [3]. The most important contact with postcolonialism lies precisely in the ideological "impulse" of the theory against postfeminism. At this point also, then, postfeminism becomes important and relevant for Indonesian context, of course for its being the so called of as "a postcolonial nation".

As has been mentioned earlier, the relevance of postfeminism, in the "ideological impulse" of postcolonialism, is a discursive (theoretical) attempt to restore femininity in accordance with its existence, in its historical considerations and cultural background. In support of post-structural theory, postfeminism grounds its issues on dominant discursive structure that works on binary opposition [[1];[2];[3]]. Thus, in this context, postfeminism does not treat gender, race, color, class, religion as the things which need to be disposed. Instead, it puts it in its own symbolic space and identity [3].

At the theoretical level, one thing to explain is who is the subject of Indonesian women's postcolonial sphere. To explain of postcolonial women certainly can not be released how the colonial construction in building the subject of Indonesian women as the former colonized nation. The construction of Western and Eastern differences, non-indigenous women-indigenous, modern and traditional women are the concept of "othering". To break out of the dominant construction of other, Indonesian women have an opportunity to build their own identity precisely in a context where women are detached from dominant symbolic criteria.

In addition, women of postcolonialism are women who are Eastern, indigenous, localized so precisely in that position the postcolonial women have the freedom to be themselves and not get caught in binary opposition or any rules of symbolic patriarchic order. In that context, the ideological impetus to become an Indonesian women, or her own locally based women, theoretically, gets its foothold.

Not long ago, an interesting poem emerged as the poem tried to establish a culture-based identity and local tradition. The poem is entitled as "Ibu Indonesia" ["Indonesian Mother"], the work of Sukmawati Soekarnopoetri. The poem dichotomizes its identity against religion (Islam). The dictation is in line with the postcolonial "ideological push". The excerpts of the poem are seen in the following:

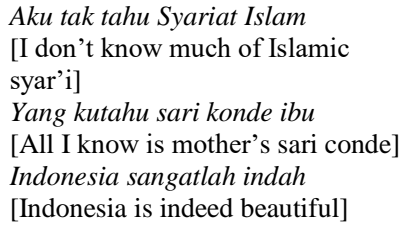




\author{
Lebih cantik dari cadar dirimu \\ [Pretier than of your veil] \\ Gerai tekukan Rambutnya suci \\ [Bending desk of her hair is sacred] \\ Sesuci kain pembungkus ujudmu \\ [As sacred as your wrapper] \\ Rasa ciptanya sangatlah beraneka \\ [Her sense creation is very much \\ diverse] \\ Menyatu dengan kodrat alam sekitar \\ [Fused with the nature of natural \\ surrounding] \\ Jari jemarinya berbau getah hutan \\ [Her fingers smelled of jungle's sap] \\ Peluh tersentuh angin laut \\ [The Sweat are touched with sea's \\ breeze]
}

Gemulai gerak tarinya adalah

ibadah

[Her dancing gestures areworship]

Semurni irama puja kepada Illahi

[As pure as the rhyme of worship to the

Divine]

Nafas doanya berpadu cipta

[Her prayer's breath melted]

Helai demi helai benang tertenun

[Knitting of pieces of strand after another]

Lelehan demi lelehan damar mengalun

[Melting after melting of damar as it's singing]

Canting menggores ayat ayat alam surgawi

[Canting scratched verses of heavenly verses of nature]

Pandanglah Ibu Indonesia

[Take a look at Indonesian mother]

Saat pandanganmu semakin pudar

[As your gaze fades]

Supaya kau dapat mengetahui kemolekan sejati dari bangsamu

[So that you know the true elegance of your nation] Sudah sejak dahulu kala riwayat bangsa beradab ini

[It has been a long time since the history of this civilized nation]

Cinta dan hormat kepada ibu Indonesia dan kaumnya

[love and respect to Indonesian mother and her people]

The interesting thing about the postcolonialpost feminist woman is the "mythical aura" when the woman of "Indonesian mother" refers to herself as part of nature, the heavenly realm, and something divine. It certainly can not be fully understood by the rational and modern world. This "unencapsulated" position also provides a vast opportunity for postcolonial women to engage in various intersections with postmodernism and other discursive structures, in separate and independent paradigmatic constructions.

\section{INTERSECTION WITH POSTMODERNISM}

When looking at postfeminist's intersection with postmodernism, in this conversation, it should be taken into a consideration of a position by putting pressure on blurring the boundaries of classification and identity. The fundamental thing of modernism, which then gets a kind of "revision" is the rejection of postmodernism against its grand naratives of modernism. Modernism with a foundation of rationality that monopolizes truth (partriarchical truth), places women in a male gaze. The dominance of partriarchal construction poses women in a series of discourses and symbolic partriarchical objects as well. Women are supposed to be aware of it or not, and not just the whole in the domination, but male gaze becomes the central point of women's existence. Therefore, it is necessary to place femininity in the female gaze itself.

The shift from male gaze to female gaze, becomes an important part in epystemological realm of postfeminism (in support of poststructuralism).This shift, as well as the politics of blurring of boundaries and identity, is not trapped in the grand narrative space. In term of female gaze, these are the small narratives, trivial and irrational reasons, and various others when women are placed independently in reality becomes possible. Whatever is narratively thought, the whole activity of womanhood is solely placed in the framework of womanhood itself. When a woman beautifies herself, both beautiful and beautifying, is for her (female gaze).

As has been already clarified, postfeminism's crossing borderor boundary crossing with poststructuralism and postmodernism, are indeed overlaping. It is due to the fact that many postmodernists' activities have adopted poststructuralists' thoughts.

\section{FEMININE FORMATION: CONTEXTUAL WOMEN}

The description of the clarification and relevance of post-feminism in Indonesia is important because it restores the existence of Indonesian women according to their different experiences, history, and background. Of course there are some natural similarities, but other experiences, such as linguistic matters, contact with the colonial/western culture, the contact with modernism, the country's gender policy, and their own local cultural experience, are not necessarily the same.

In Indonesia, there are at least two dominant languages, namely the Indonesian national language [Bahasa Indonesia], and the local language [regional language] that is commonly identified with the mother tongue. Indeed, local languages have different characters, but in general the local language region is related to semiotic and local values. Proverbs with local values and wisdom, for example, can only be understood by the local community. Quite a good deal of local wisdom is patriarchically biased, but at the point of separation (when women are allowed to) can be used to develop independent female values.

The national language of Indonesia is political and rational, and mother toungue language is 
cultural and "more emotional". This dichotomy is clearly irrelevant to postfeminist paradigmatic buildings. However, what has to be taken is precisely at the point of separation itself. When it has been separated as something "more emotional", something that is, in a dominant structure building, then postfeminism actually utilizes the emotional freedom independently without having to account for anything else. Thus, postfeminists should have a bias towards something considered to be the mother tongue, the language of women.

Indonesia's colonial experience can be summed up as an experience as a subject that is never taken into account, to say almost nothing. Layers of the colonial hierarchy of power structures, causing indigenous women to occupy the lowest place. Indonesian literary works during the colonial period generally manifested this. Women are no more than objects of patriarchal subjects.

In the post-colonial period, during the revolutionary period, Indonesian women entered into the subjects of the people, although still part of the subject of the men. During the New Order period, the country made Indonesian women enter the phase of Ibuism, a dual role in addition to being Indonesian women who were expected to appear cultured and civilized. As the feminism of the first and second waves progressed, the role of the state in positioning Ibuism got a lot of resistance. Especially if it were associated with state intervention in the issue of regulation of sexuality and reproduction. The thing that needs to be concluded in the above brief explanation is that under each discursive regime, there always arises a new woman's role and existence.

\section{CONCLUSION}

Thus, the meaning of postfeminist women is women who build their own paradigm in some of the following assumptions. First, building ideological support for local languages and cultures which are dominated by dominant cultural constructs. Contextual women are contextual subjects who build consciousness based on a subject formation and feminine identity in relevant to the situation and demands of the needs of their time. Contextual women are contextual subjects who appear as women without putting themselves in a patriarchal discursive order.

Based on the subject and the identity of femininity who experienced the construction of postcolonial discourse, postmodernity, and the attraction of local culture, Indonesian postfeminist women challenged the great difficulty to become contextual women. There are, here, two sides of a contradictory situation or a diversed standpoint. First, on the one hand state policies that are patriarchal and rationally biased minimize the possibility of post-feminist women, but on the other side, there is an ideological urge to return to their respective local cultures. Second, in the one hand it has its own paradigm of independence, but on the other it demands of religious values and local culture that in fact is still under the partriarchical grip. Hence, following Adriaens', McRobbie's, and Genz and Brabon's suggestions, postfeminism does not have its own pattern in constructing a methodological guideline in developing its discursive model of analysis. It is only an academic contribution in rethinking the new model of analysis which grounds its own footstep from within the perspective of women and their own world.

\section{REFERENCES}

[1] F. Adriaens, "Postfeminism in popular culture: A potential

[1] : A potential for critical resistance?" In Politics and Culture, ed. 2009 Issue 4

[2] A. McRobbie, "Post-feminism and popular culture: Bridget Jones and the new gender regime" in The aftermath of feminism: gender, culture and social change. London: Sage, 2009, pp. 11-23

[3] S. Genz and B. A. Brabon, Postfeminism: cultural texts and theories. Edinburg: Edinburg Universiry Press, 2009

[4] A. Brooks, Feminism and Cultural Studies. Yogyakarta: Jalasutra, 2011.

[5] S. Mills,Discourse. London and New York: Routledge, 1997.

[6] M. Foucault, "The Order of Discourse", in Robert Young'sUntying The Text: A Post-Structuralist Reader. London and New York: Routledge and Keagan Paul, 1987.

[7] M. Foucault, Power/Knowledge: Wacana Kuasa/Pengetahuan. Yogyakarta: Bentang, 2002.

[8] C. Belsey, Critical Practice. London and New York: Methuen, 1980

[9] N. Mansfield, Subjectivity Theories of the Self from Freud to Haraway. Sydney: Allen \& Unwin, 2000.

[10] S. Hall, "The Question of Cultural Identity", in Stuart. Hall, D. Held and T. McGrew (eds.). Modernity and Its Future. Cambridge: Polity Press, 1992.

[11] P. Bourdieu, Distinction. London: Rouledge, 1984.

[12] R. Putnam Tong. Feminist Thought. Yogyakarta: Jalasutra, 2008. 